\title{
Spectres of Agency
}

\section{The Case of Fóstbroðra saga and its Distributed Author}

\begin{abstract}
Drawing on the current studies of memory, agency, and artificial intelligence, this chapter revisits the concept of the 'distributed author' which, some years ago, I proposed as a way of encapsulating the complex dynamics between the communal and individual creativity that characterises medieval authorship. With its unusual patchwork structure that renders visible the spectres of the multiple overlapping agencies that brought it to being, Fóstbrœðra saga is used as a particularly amenable case study to illustrate this evolutionary, networked way of thinking about medieval authorship, and perhaps also authorship in general.
\end{abstract}

Keywords

Distributed Author, Artificial Intelligence, Memory, Manuscript Culture, Fóstbrœðra saga

\section{What Can We Learn about Authorship from AI Storytellers?}

In early 2019, at the OpenAI research laboratory in San Francisco, a group of scientists conducted an experiment with (or, rather, played a little joke on) the artificial neural network they named GPT-2, whereby they challenged it to produce a plausible newspaper article based on the following, entirely implausible prompt:

In a shocking finding, scientist [sic] discovered a herd of unicorns living in a remote, previously unexplored valley, in the Andes Mountains. Even more surprising to the researchers was the fact that the unicorns spoke perfect English. ${ }^{1}$

While continuing on from such an opening might have posed a considerable headache even to a seasoned journalist, GPT-2 proved itself well suited to the task. Despite the brevity of the human-written prompt and the improbability of its content, the machine produced a fully-fledged and remarkably detailed article in which not only are a credible name, area of expertise, and academic affiliation of the lucky researcher provided ("Dr. Jorge Pérez, an evolutionary biologist from the University of La Paz"), along with

1 Cf. Radford et al. 2019a, Table 13; or Radford et al. 2019b, first sample. 
a description of the animals themselves ("four horned, silver-white"), their natural habitat ("the valley had what appeared to be a natural fountain, surrounded by two peaks"), and the name of their species ("Ovid's Unicorn"), but a few possible explanations of the origins of these "bizarre creatures" are also put forward. ${ }^{2}$ As to which of the three proposed theories is most likely to be correct - i.e. whether the Argentinian-born, English-speaking unicorns are "descendants of a lost race of people", the result of a possible cross-breeding ("when a human and a unicorn met each other"), or even "a lost alien race," - the article defers to the expertise of "Dr. Pérez" who, as befits a conscientious scientist, suggests that "the only way of knowing for sure" is "through DNA" testing. ${ }^{3}$ Thus, without being given any instructions to that effect, GPT-2 not only applied the appropriate generic conventions in writing its article, but also attempted to address the very implausibility of its content. In other words, this inanimate computer programme appears to have somehow picked up on the words "shocking" and "surprising" from the initial prompt and appears 'aware' of the fact that its readers would expect some explanation for the incredulous discovery it reports.

Where do this apparent awareness and the numerous other intuitions regarding the article-writing conventions come from, if they were not built into the programme? Not only did the scientists not attempt to teach GPT-2 any rules (e.g. those pertaining to grammar and language in general, or to writing newspaper articles in particular), they did not even train it to identify task-specific concepts such as, in this case, 'unicorn', 'scientist', or 'shocking'. Instead, they let GPT-2 learn implicitly in an evolutionary manner, which is to say on the principle of trial and error. The 'teaching materials' or dataset on which this particular algorithm (or the 'language model', as its creators refer to it) is trained comprise eight million web pages (sourced from Reddit) ${ }^{4}$ of varied, humangenerated text, and, according to Radford et al., "GPT-2 is trained with a simple objective: predict the next word, given all of the previous words within some text. The diversity of the dataset causes this simple goal to contain naturally occurring demonstrations of many tasks across diverse domains." ${ }^{5}$ Apparently, simply by getting better and better at predicting the next word in a given text, GPT-2 was eventually able to generate complex, coherent pieces of writing, such as the article on unicorns.

It seems surprising that there should be nothing more to GPT-2's authorship than following this simple principle and the corpus of texts (enormous and varied though it is) on which it has been trained, and yet in a sense it is not surprising at all, for it seems only

2 Radford et al. 2019b.

3 Radford et al. 2019b.

4 Reddit is a social media platform, an online forum comprising user-generated content, news, conversations, images, videos, etc. For more, see https://www.reddit.com/ (last accessed 1 March 2021).

5 Radford et al. 2019b. 
to lend some 'hard' scientific support, or offer the proof of concept, for the already familiar postmodernist ideas about authorship and creativity (still often perceived as poetic abstractions and metaphors), in which a text, instead of being conceptualised as having a human genius at the centre of its origin, is construed as "a tissue of quotations drawn from innumerable sources of culture", ${ }^{6}$ as a machine of sorts: "to write is to produce a mark that will constitute a kind of machine that is in turn productive." Now, we quite literally have machines produced by writing that are capable of producing writing in turn.

To be sure, machine learning algorithms such as GPT-2 still fall short of fulfilling scientists' ultimate dream of creating an artificial intelligence that would be on par with that of humans, but they are nonetheless with ever-increasing velocity taking that dream out of the realm of impossibility. ${ }^{8}$ Fascinating though it is, GPT-2's article on unicorns is far from being perfect, as despite its overall coherent narrative it also features a few linguistic and logical infelicities, sometimes resulting in unintended hilarity as, for example, when, following on from the hypothesis about possible prehistoric human-unicorn sexual encounters, Dr. Pérez comments that "in South America, such incidents seem to be quite common". ' Of course, to a lesser or a greater degree, this is also often the case with human-generated articles, such as the one you are reading presently, which was bound to undergo a few revisions before the editors (and the culprit who had perpetrated it) were happy for it to be published. Whilst machines such as GPT-2 may not yet be able to produce a page-turner that would keep us riveted to our armchairs for hours on end, the day when we will be able to type in (or simply voice) a request for 'an Austenesque novel with a sprinkling of Kafka and a pinch of Saxo Grammaticus' might not be that far off either. For now, however, machine learning algorithms such as GPT-2 provide us with unprecedented insights into our own human creativity and with unprecedented transparency too, as the compact oneness of our skulls makes it all too easy to forget that concealed within each of these individual nutshells is also a neural network, something that is one and many all at the same time. To be sure, in some important details these two kinds of networks - the human brain and machine learning algorithms - significantly differ from one another, not least when it comes to the brain's organic substratum, its (currently) vastly larger number of neurons, and the far greater complexity and intricacy of the connections between them that, among other things, enables the brain to perform many heterogenous tasks simultaneously. ${ }^{10}$ And yet, inasmuch as both can be described as webs of interrelated nodes where each

6 Barthes 2000, p. 128.

7 Derrida 1982, p. 316.

8 See Pavlus 2020 on the important inroads recently made towards the programmers' Holy Grail of getting artificial neural networks to develop common sense.

9 Radford et al. 2019b.

10 Cf. Schiappa / Rudd 2017. 
connection between two nodes is weighted (i.e. has a particular value: negative / positive, stronger / weaker, etc.), and where each node has many inputs but produces a single output which is in turn broadcast to many other nodes, the brain and artificial neural networks such as GPT-2 can be said to be structurally and functionally analogous. The study of one therefore directly impacts upon the study of the other. From our point of view, it is precisely GPT-2's comparative simplicity in relation to the brain that makes it so amenable in the first place to interdisciplinary study (of the generation of texts, in this case). In particular, the finite number (eight million) and tractability of its influences (the Reddit dataset) ensure that any resulting creative behaviour of this algorithm cannot be ascribed to some mysterious, ingenious ingredient ' $\mathrm{X}$ '.

In parallel with the developments in machine learning and artificial intelligence, recent studies of memory and cognition are further dispelling the myth of the genius as a single source of origin by exposing the variety of ways in which memory (which is also to say learning and creativity), this most intimately experienced faculty of our individual brains, can be understood as a profoundly communal phenomenon. ${ }^{11}$ From the basic, physiological makeup of the brain, which, with its more or less densely interconnected neurons and neuron populations, bears an architectural and functional resemblance to a society (a "parliament of [...] selfhood;" ${ }^{12}$ ), to the ultimate embeddedness of personal memory in inherited cultural narratives (including the very construals of self $\left.^{13}\right)$, as well as its dependence on and susceptibility to social influence, ${ }^{14}$ all the evidence points away from the singular, monolithic notion of the self towards a picture of multiple and malleable selves. In line with the thinking that has been around within the humanities for some time now, the current research in cognitive sciences offers further support for conceiving of identity, subjectivity, and personhood not in terms of immutable essences, but as being continually constructed, performed, and recreated in relation to our natural and cultural environments. Whilst terms such as 'constructed' or 'culturally situated / embedded' may carry the unfortunate connotation of disingenuousness and invoke the unpleasant image of the human as a socially controlled drone, the actual implications of current theories of memory, identity, agency, and personhood could not be further from such dystopian horrors. If anything, our capacity to adapt, change, and evolve in response to our milieus - rather than being defined from birth by a set of unchanging characteristics, some 'quintessence' that would confine and predetermine our every move - can be seen as liberating and empowering, making us active stakeholders in our societies, not merely their products.

11 Cf. Ranković 2010; Ranković 2018.

12 Cf. McEwan 2011, p. 262.

13 Cf. Nelson 2003; Wang 2011.

14 Cf. Hirst / Brown 2011; Dudai / Edelson 2016. 


\section{The Long Shadow of the Author-Genius}

Beyond the narrow confines of academia, the above ideas have been gaining wider, popular currency and have influenced the way in which authors today think of themselves too. Here, for example, is what one of my favourite living novelists says of her own shifting selfhood in a recent interview:

"You are talking to a surrogate, facsimile version of Margaret Atwood," says, well, Margaret Atwood. "[Y]ou make a version of yourself that does the publicity. There is always an edited version, a presentation, always, even if you're saying: "this is the innermost secret of the core of my being", it is still a presentation. [...] You are talking to a made-up person." ${ }^{15}$

It is all the more paradoxical, then, that this comment by Margaret Atwood, at once playful and serious, was made in the context of the recent controversy that sprang up around the frenetic quest to uncover the 'true' identity of yet another self-confessed avatar - the famously anonymous Italian novelist writing under the pseudonym Elena Ferrante. Here we have an author who is literally, ardently attempting to embrace the spectral, 'facsimile' version of her public persona, which she named 'Elena Ferrante,' only to find her human host the subject of a relentless hunt. ${ }^{16}$ Clearly, counter to the notions of the fluidity and provisionality of the self, as well as the various ways in which a literary work becomes autonomous from its creator, there still runs the desire for the author-genius, the need to point to a single, palpable source of origin so that creation can be explained and demystified, though only inasmuch as it leaves in its place a figure in our own familiar image to continue to worship, a figure by which one can continue to be mystified.

of the various attempts at revealing the culprit behind the pen name Elena Ferrante, the one that gained most traction was that of the investigative journalist Claudio Gatti, who, in 2016, conducted a covert enquiry into the financial transactions of the novelist's publisher, which led him to claim that the person behind the pseudonym is not someone - as the readers were led to believe - who wrote from her immediate, personal experience of growing up in a post-war Naples slum, but the ten-years younger, Rome-based translator Anita Raja. A year later, a team of computer scientists and forensic linguists from the University of Padua suggested Raja's husband, the author and journalist Domenico Starnone, as the more likely candidate. ${ }^{17}$ Neither of these theories has been definitively proven, but Gatti's article in particular has stirred up a great deal of controversy in literary circles, with some writers accusing him of maliciousness,

Wilson 2016.

16 E.g. see Gatti 2016; Savoy 2018.

17 Cf. Tuzzi / Cortelazzo 2018. 
sexism, and gross invasion of privacy, ${ }^{18}$ asserting that it is after all the books that should matter the most, not least because that is where their author's 'true self' is supposed to reside anyway. Gatti's defence was that the mystery surrounding Ferrante's anonymity, coupled at the same time with a complete, fake biography of the 'author', is a venally motivated ploy to boost the sales of the books, which is why he says he was motivated to debunk it.

When asked how important she thought knowledge of an author's identity to be, Atwood replied: "I mean, is it the most important thing? No. Will it influence how people approach the books? Yes." ${ }^{19}$ For this reason, the question of authorship will probably never be a trivial matter - even when it comes to the medieval kind of authorship, where those of us who study it are confronted daily with texts that often have roots in oral tradition; texts that are composed, copied, and compiled not by one person, but by a series of creative individuals who remain anonymous to us, some accidentally, some on purpose; texts that are, in a very palpable sense, products of centuries-long evolution, ${ }^{20}$ ever-adapting to the changing tastes and needs of their audiences, and consequently often surviving in more versions than one, whether as wholes or in fragments. As items of such complex, multi-layered textuality, even when trapped in scholarly editions, these narratives tend mutinously to dissolve the linear boundaries imposed upon them, escaping through footnotes that call upon divergent manuscript readings and relationships to other texts in the corpus and that feature editorial clarifications and justifications of inclusions and exclusions. Under such circumstances, what use is it to know who it was that first committed this or that story to parchment (a moment that still seems to exert privilege), especially if, as was the case with the sagas of Icelanders, these individuals were themselves aware that the story came well before them and would continue to be told and retold well after them? Although Margaret Atwood is undoubtedly right to propose that such knowledge is likely to influence the way we read these texts, the question is what kind of influence it would exert and how far it would extend.

E.g. see Winterson 2016.

Wilson 2016.

It is important to distinguish between evolution as a scientific theory that relates to complex processes of gradual change of entire species of variants (i.e. across a population - horizontally / synchronically and over time - vertically / diachronically) and the more popular usage of the term that conflates evolution with genesis and the pre-Darwinian idea of the 'great chain of being' which assumes a linear chronological progression from 'lower' towards 'higher', 'more perfect' entities. Throughout the present chapter, it is in the former, more rigorous sense that the concept of evolution is employed. 


\section{Spectres of Agency in Fóstbrœðra saga}

Fóstbrœðra saga is an interesting case to consider in this regard. Being a bit of an oddity within the Íslendingasögur (sagas of Icelanders) genre, this text forcefully draws attention to the idiosyncratic agency that has had a hand in shaping it. Whilst it closely adheres to various conventions of the genre in terms of its content (e.g. revenge-taking, a blood-brotherhood that turns sour, the Icelander-king encounters, etc.), Fóstbrœðra saga also espouses bold stylistic departures, appropriating apparently incongruous discourses - medical, religious, romance - and featuring a sporadically ornate mode of expression, as well as a narratorial voice prone to occasional pontificating and passing explicit ethical judgements. Thus, when the repentant pormódr manages to win back the favour of his lover pórdís by re-dedicating to her the verses he had previously and treacherously bestowed upon Porbjorg kolbrún, the reader is treated to an elaborate simile, so profoundly uncharacteristic of a genre that famously adheres to terse expression and prefers 'showing' to 'telling':

Ok svá sem myrkva dregr upp ór hafi ok leiðir af með litlu myrkri, ok kømr eptir bjart sólskin með blíðu veðri, svá dró kvæðit allan órœkðar pokka ok myrkva af hug pórdísar, ok renndi hugarljós hennar heitu ástar gørvalla til pormóðar með varmri blíðu. ${ }^{21}$

And like the dark mists that are drawn up out of the ocean, dispersing slowly to sunshine and gentle weather, so did these verses draw all reserve and darkness from Thordis' mind and Thormod was once again bathed in all the brightness of her warm and gentle love. ${ }^{22}$

Whilst such a picturesque outpouring of sentiment would not be out of place in a medieval romance, one would be hard pressed to find even one other example of it in the entire Íslendingasögur corpus, save Fóstbroeđra saga itself.

Similarly uncharacteristic is the expert medical (and religious) explanation of porgeirr's otherwise formulaic heroic restraint, as manifested in his lack of reaction to the devastating news about his father's slaying: ${ }^{23}$

Eigi roðnaði hann, pví at eigi rann honum reiði í hǫrund; eigi bliknaði hann, pví at honum lagði eigi heipt í brjóst; eigi blánaði hann, bví at honum rann eigi í bein reiði, heldr brá hann sér engan veg við tíðenda sǫgnina, pví at eigi var hjarta hans sem fóarn í fugli; eigi var pat blóðfullt, svá at pat skylfi af hræzlu, heldr var pat hert af inum hæsta hǫfuðsmið í ollum hvatleik. ${ }^{24}$

21 Fóstbrœðra saga, ch. 11.

22 Unless otherwise stated, all the accompanying English translations are by Martin S. Regal (The Saga of the Sworn Brothers, here p. 355).

23 On the 'no reaction' formula, see Ranković 2017, pp. 385-390; for its specific applications to Porgeirr, see Ranković 2020, pp. 115-119.

24 Fóstbrœðra saga, ch. 2. 
His face did not redden because no anger ran through his skin. Nor did he grow pale because his breast stored no rage. Nor did he become blue because no anger flowed through his bones. In fact, he showed no response whatsoever to the news - for his heart was not like the crop of a bird, nor was it so full of blood that it shook with fear. It had been hardened in the Almighty Maker's forge to dare anything. ${ }^{25}$

This theory about God being the ultimate craftsman of porgeirr's brave, sturdy heart soon becomes a catalyst for a mini-sermon on free will - yet another atypical feature for a saga:

Ok af pví at allir góðir hlutir eru af guði gọvir, pá er øruggleikr af guði gǫrr ok gefinn í brjóst hvǫtum drengjum ok par með sjálfræði at hafa til pess, er peir vilja, góðs eða ills, pví at Kristr hefir kristna menn sonu sína gort, en eigi bræla, en pat mun hann hverjum gjalda, sem til vinnr. ${ }^{26}$

And as all good things come from God, so too does steadfastness, and it is given unto all bold men together with a free will that they may themselves choose whether they do good or evil. Thus Jesus Christ has made Christians his sons and not his slaves, so that he might reward all according to their deeds. ${ }^{27}$

On less grave occasions, Fóstbrœðra saga uses similar displays of erudition and devoutness to create comical effects. This occurs, for example, in the scene in which pormóðr's hapless dupe, Egill the Fool, gets so alarmed that, we are told,

Qll bein hans skulfu, pau sem í váru hans líkama, en pat váru tvau hundruð beina ok fjórtán bein; tennr hans nǫtruðu, pær váru prír tigir; allar æðar í hans hǫrundi pipruðu fyrir hræzlu sakar, pær váru fjogur hundruð ok fimmtán. ${ }^{28}$

Every bone in his body shook, all two hundred and fourteen of them. All his teeth chattered, and there were thirty of them. And all the veins in his skin trembled with fear, and there were four hundred and fifteen of them. ${ }^{29}$

At every turn we encounter such idiosyncrasies that make us wonder who the author of Fóstbrœðra saga might have been - a priest, a doctor, both? - where he travelled, what he read, what sorts of literary influences he was exposed to, and what may have possessed him to stray from convention and risk experimenting in such quirky ways.

25 Regal: The Saga of the Sworn Brothers, pp. 332f.

26 Fóstbrœðra saga, ch. 3.

27 Regal: The Saga of the Sworn Brothers, p. 336.

28 Fóstbrœðra saga, ch. 23, p. 233, n. 3.

29 Regal: The Saga of the Sworn Brothers, p. 378. 
Yet, as soon as we ask these questions, we must also ask in the same breath: Which author and which Fóstbroðra saga do we have in mind exactly? As is the case with all other sagas, the first written version of Fóstbrœðra saga does not survive; and, what is more, the text that we encounter when we open the Íslenzk fornrit edition is a proper Frankensteinian creation. Its first eleven chapters are made up of the incomplete Möðruvallabók version of the saga (henceforth $\mathrm{M}$ ), dated to c. $1350 .^{30}$ From there, the main text continues to follow the story according to this same venerable saga codex, but with the Hauksbók version ( $\mathrm{H}$; dated to the first third of the $14^{\text {th }}$ century) ${ }^{31}$ now running in parallel with it, though consigned to the lower part of the page as a secondary source. This goes on until around the middle of chapter 20, when the M text abruptly breaks off, whereupon the $\mathrm{H}$ version becomes the primary text. On top of that, the scenes unique to yet another manuscript, the late $14^{\text {th }}$-century Flateyjarbók $(\mathrm{F}){ }^{32}$ have been intermittently inserted into the main text, only rendered in a smaller font to make the editorial interpolations visible.

Despite these precautions, critics have rarely resisted the temptation to ignore the patchwork nature of this text and to treat it as a continuous whole. This has proven to be perilous, especially when it comes to the assessment of porgeirr Hávarsson's character. Whether he is charged with "sterile self-assertion" and "senseless violence" 33 or with "the unbalanced, perhaps demonic lack of restraint", ${ }^{44}$ two particular scenes are regularly invoked as evidence of porgeirr's unbridled behaviour. In one, he kills a certain Torfi Bundle, ${ }^{35}$ thinking that the latter was purposefully, insolently ignoring his questions when the man simply could not hear him because of the rushing stream nearby; in the other, he chops off the head of a shepherd for seemingly no better reason than

30 This dating is according to the Íslenzk fornrit editor of the saga, Guðni Jónsson 1943, p. LXX (see also Chesnutt 2001, p. LXVIII). However, a broader time period for the production of this codex is 1320-1370, with Einar ólafur Sveinsson arguing for an earlier dating (1320-1350) and Jón Helgason for a later one (1350-1370). For more detail, see Chesnutt 2001.

31 See Guðni Jónsson 1943, p. LXX. More recently, Johansson (2018) has drawn attention to the composite structure of the Hauksbók as a whole, showing how the manuscripts it comprises (AM 371 4to, AM 544 4to and AM 675 4to) in turn consist of variously sized individual leaflets produced at different times, some even well after the death (in 1334) of its compiler and scribe, Haukr Erlendsson, after whom the codex is named. Johansson's arguments are instructive and illuminating, especially when it comes to trying to infer Haukr's 'intentions' regarding the choice of texts and their specific ordering; however, they do not affect the dating of the part of AM 544 4to that contains Fóstbrœðra saga, which features Haukr's own hand and for which 1334 is therefore the terminus ante quem. Guðni Jónsson (1943, p. LXX) dates Flateyjarbók to c. 1390. Rowe (2005, pp. 11f.) notes that the work on this imposing codex commenced in 1387, with the last entries in the annals dated to 1394. Cf. Meulengracht Sørensen 1993, pp. $406 f$.

34 Harris 2015, p. 81.

35 Cf. Fóstbrœðra saga, ch. 8. 
that his neck was conveniently sticking out and that he hence stóð svá vel til hoggsins ${ }^{36}$ ("stood so well poised for the blow" ${ }^{37}$ ). Even if we ignore the clear elements of slapstick humour in these scenes of 'senseless violence', what we cannot afford to ignore is that they are both in fact unique to the F version of the saga and are distinctly at odds with the way porgeirr is portrayed in $\mathrm{M}$ and $\mathrm{H}$. To be sure, in those two versions we are also explicitly told that porgeirr is a difficult, overbearing character, but in direct contrast to these overt pronouncements, in each of his conflicts the hero is actually shown to behave with utmost restraint and measure. ${ }^{38}$ porgeirr's sworn brother pormóðr is in F also portrayed as a far more unruly character (in Fóstbrœðra saga and pormóðar páttr alike) than in $\mathrm{M}$ and $\mathrm{H}$. According to Úlfar Bragason, the crucial difference here is probably due to the fact that, in the $\mathrm{M}$ and H versions, porgeirr and pormóðr are the ultimate heroes of the saga, whilst in F they only play the sidekicks to St. Óláfr Haraldsson, who is the actual hero. ${ }^{39}$ The Fóstbrœðra saga featured in $\mathrm{F}$ is a subordinate narrative, its various segments pulled apart and inserted into óláfs saga helga, which is treated as the main text. From this perspective, it would have paid off to accentuate the sworn brothers' irascibility, with their unfavourable characteristics being used to offset the virtues of the saintly king. This accords well with how, in a short preamble, the compiler of F, Jón pórðarson, himself justifies the inclusion of Fóstbrœðra saga in his lavish codex: "From this, one must notice the grace and good luck of King Óláfr, that he showed that restraint to such terribly unruly men as these foster-brothers were, who loved the king above all other men." ${ }^{40}$ Whilst it is unlikely that Jón Pórðarson invented those two episodes in chapter 8 - after all, Grettis saga likewise casts porgeirr in an unfavourable light ${ }^{41}$ - it could be argued that he nevertheless successfully appropriated traditional material to fit his particular agenda, which, as Elizabeth Ashman Rowe persuasively argued, was probably to frame St. Óláfr and his kind treatment of Icelanders (even the unruly ones) as an example to that king's teenage namesake, King Óláfr IV Hákonarson, for whom $\mathrm{F}$ was intended as a gift. ${ }^{42}$

Nor is Jón Pórðarson's the only agency that can be discerned in Fóstbrœðra saga. The way in which a particularly charged conversation between King óláfr and porgeirr has been presented differently in $\mathrm{M}$ and $\mathrm{H}$ respectively is an excellent case in point. In both scenes the king asks porgeirr to sail to Iceland and avenge one of his retainers - not only to punish the Icelandic culprit, but also to set a general example to Icelanders, as

Fóstbrœðra saga, ch. 8.

Regal: The Saga of the Sworn Brothers, p. 347.

Cf. Ranković 2020, pp. 110-125.

Úlfar Bragason 2000, pp. $272 \mathrm{f}$.

Cited in Rowe 2005, p. 57.

Cf. Ranković 2020, pp. $114 \mathrm{f}$.

cf. Rowe 2005. 
a deterrent for the irksome liberties they seem to allow themselves. Compare, however, the different replies that the king receives. In $\mathrm{M}$, the hero's answer is rather circumspect, which seems to betray some reluctance and discomfort on his part:

porgeirr svarar: "Bat væntir mik, at ek muna hefnt fá pessa mótgørða, er yðr hafa gorvar verit í pessu verki." Konungr mælti: "Dví býð ek pér um petta mál, at ek hygg, at pú munir minn vilja gera í pessu verki." porgeirr svarar: "Skyldr em ek til pess at gera pat, sem pú vill." ${ }^{43}$

Thorgeir answered, "I expect I will be able to avenge this offence against you." The king said, "I am asking you because I believe you will do my will in this matter." Thorgeir replied, "I am obliged to do as you bid me." ${ }^{44}$

By contrast, in H, Porgeirr needs no further prodding by the king, nor does he acquiesce merely out of obligation. Instead, he gives an instant, concise, strongly affirmative answer: Pat skal ek gjarna gera ${ }^{45}$ ('That I shall willingly do'; S. R.). Of course, in line with Margaret Atwood's point earlier, knowing that the person behind the words imputed to Porgeirr was Haukr Erlendsson will inevitably impact our interpretation of them. In this case, it might make us less inclined to take them as an arbitrary variation: as an Icelander who held the office of lawspeaker both in his native land and in Norway, and who was himself a retainer of Norwegian kings (Hákon V and later Magnús VII), Haukr was likely to be intimately familiar with how an appropriate answer to a royal command should sound, especially as, by his time, the Norwegian Crown had well established its rule in Iceland. Conversely, given the M's scribe apparent tendency to adhere to his exemplars, ${ }^{46}$ it is tempting to conjecture that, even though it is a few decades younger than $\mathrm{H}$, the $\mathrm{M}$ text may in fact preserve the older, more varied set of attitudes from when Iceland's status was still in flux, unresolved - a circumstance that would be particularly amenable to a parallel circulation of more disparate, ambivalent, and perhaps even contradictory discourses regarding the Icelanders' relationship to Norwegian royalty.

Fóstbrœðra saga, ch. 13.

Regal: The Saga of the Sworn Brothers, p. 358.

Fóstbrœðra saga, p. 183.

This is a tentative claim based on my detailed investigation of the usage of the formula pair sem fyrr var sagt/ritat in this codex (cf. Ranković 2016, pp. 321f.). While the individual sagas in M show consistency in this regard (consider, for example, Laxdœela saga's clear preference for the written mode of the formula), the employment of the formula in the codex as a whole is widely varied from saga to saga. The lack of a more homogenous overall usage indicates that the scribe was most likely following his exemplars. This, of course, is not sufficient evidence to prove that the M scribe did not diverge from his exemplars in other ways, but it may point to certain conservative tendencies on his part. 
Nor is this instance the only one in which Haukr intervenes. ${ }^{47}$ Remember that florid passage about pórdís allowing pormóðr to bathe once again in "the brightness of her warm and gentle love"? Haukr, it seems, would have none of that sentimentality; instead, he simply notes that pormóðr's re-dedication of the incriminating verses won him back pórdís' love and affection, and that consequently “teksk nú upp með peim ný vinátta" 48 ('a new friendship arose between them'; S. R.). Other such stylistically unusual passages, which, if Jónas Kristjánsson is right, were all part of the first written version of Fóstbrœðra saga, are also regularly culled by Haukr, including that concerning Egill the Fool and his thirty chattering teeth. ${ }^{49}$ of course, an argument can be made here that a preference for succinct expression is general tendency of Haukr's - perhaps more a matter of practicality and convenience than of aesthetics, considering the encyclopaedic size and ambition of $\mathrm{H}$, which, in addition to sagas such as the one presently discussed, contains all kinds of texts, from historiography and myth to mathematical lore. Yet it does not seem like a pure coincidence that it is precisely the stylistically aberrant passages that are cut off from his redaction of Fóstbrœðra saga. Moreover, if pruning his exemplars were Haukr's general rule, we would hardly expect him to expand on the received material, which he in fact does on occasion.

One interesting intervention of this sort takes place in chapter 15 of the saga, in which porgeirr is forced to share quarters with his enemy Gautr Sleituson before the ship on which they had both secured passage can sail off to Norway. Having searched for an opportunity to provoke Porgeirr ever since the slaying of his relative Porgils Másson, Gautr finally finds it when the hero and his men leave the camp to gather firewood. Instead of waiting for the party to return, Gautr proceeds to cook his meal by using porgeirr's shield and spear as kindling. This offence, conversely, offers porgeirr a chance to take the higher ground and exercise restraint instead of taking instant revenge. Thus, when Gautr responds to his request for explanation for this extreme action only by adding further insult to injury, saying that he had burnt borgeirr's weapons because he did not fancy eating his food raw, in the M version of the saga we are told that nú fann ekki á Porgeiri, at honum mislikaði sjá tiltekja Gauts" ("there was no indication from Thorgeir that he was upset by what Gaut had done"51). This exemplary employment

47 In addition to Haukr's own hand, four other scribal hands have been detected in the $\mathrm{H}$ version of Fóstbroðra saga. Of these, the most prominent (after Haukr himself) is 'Hand 9', often referred to as 'Haukr's first Icelandic secretary' (cf. https://handrit.is/en/manuscript/view/en/AM04-0544, last accessed 1 March 2021), with only minor contributions by Hands 10-12. The examples discussed here fall within the part written by Haukr, but even if this were not the case, other scribes will presumably still have worked under his direction / supervision.

51 Regal: The Saga of the Sworn Brothers, p. 364. 
of the traditional device mentioned above - namely, the 'no reaction' formula - subtly undermines the overt narratorial pronouncements about porgeirr's hot-headedness by placing him in the illustrious company of other worthy saga heroes capable of controlling their tempers and of taking revenge for the offences perpetrated against them not in the first instance, but later on with the advantage of temporal distance, broader perspective, and cooler reasoning. The $\mathrm{H}$ version of Fóstbrœðra saga goes a little further than $\mathrm{M}$ in emphasising porgeirr's self-control, expanding on the 'no reaction' formula by showing the hero to affirm (if only in mock-seriousness) Gautr's purposefully feeble excuse; porgeirr goes as far as elaborating on the legal necessity of cooking one's food, referring both to the Icelandic laws on this matter and to his Norwegian liege, King óláfr, who, porgeirr calmly informs his stunned audience, strictly forbade his men to eat their food raw. ${ }^{52}$ The scene thus becomes imbued with humour and suspense, for the more that Porgeirr 'helps' his enemy to make him the butt of the joke now, the sweeter his last laugh will be at the end of the chapter.

Again, even though a keen interest in legal matters is one of the characteristic features of the saga genre (which in itself might not be a coincidence, but rather an indication of a good proportion of lawmen among the saga writers), knowing what we know about Haukr's life and career makes it difficult to ignore the possibility of a personal touch, i.e. that in the above instance he could not resist putting his professional knowledge to the service of saga humour. The question now arises as to whether this agency that we purport Haukr might have exerted upon his Fóstbrœðra saga exemplar was more or less authentic, more or less authoritative than that exercised by the person (read: culprit) who we deem responsible for the first written version of that narrative - 'the author?' After all, Haukr did nothing but make his own version of Fóstbrœðra saga sound more like a saga, bringing it closer in spirit to the tradition on which the errant author also drew. His 'legal joke', for instance, certainly has more of the ring of a traditional saga to it than does the shaking of the two-hundred-and-fourteen bones belonging to Egill the Fool. Thus, paradoxically, what makes Haukr's touch seem 'personal' is reflected in how deeply traditional it is. Then again, we might also ask whether the 'author's' stylistic experimentation is itself so utterly foreign to tradition, considering that every living tradition must also change in order to survive. As I have discussed elsewhere, ${ }^{53}$ modern folklore research shows that oral singers and storytellers bring all sorts of novelty into their renderings of familiar narratives, novelties that can be appreciated as such only against the background of tradition on which they are dependent. However, in the absence of a literate collector ready to record them, such novelties are unlikely to survive unless they happen to appeal to the audience enough to be instantly picked up and transmitted further. As the latter scenario tends to be extremely rare (partly due to 
the fleeting nature of oral performance, partly to the inertia of the already familiar), it often happens that the same invention must consequently be invented multiple times by multiple people and in multiple locations before it enters the common idiom and becomes the part of tradition.

If, then, all these ‘doers' - the anonymous saga writer, Jón Pórðarson (the previously discussed compiler of F), and Haukr Erlendsson - can be said to have acted authentically and authoritatively, each according to his own agenda (often also a manifestation of a larger social agenda), what about the 'humble' M scribe? He seems a passive enough fellow, diligently copying the text before him - is his agency of a lower order? Not in my opinion. Were it not for his diligence (or was it a latent defiance to Norwegian overlordship?) - which, we must not forget, is not mandatory in a fluid manuscript culture, but is always a choice - all the traces of that provocatively circumspect response by porgeirr to King Óláfr's interference in Icelandic affairs would have disappeared, and with it the intricate tension that now suddenly flares up between porgeirr's long (M) and short (H) answers, enriching our understanding of the saga and the various cooperating and competing social, ethical, political, and aesthetic forces and attitudes that participated in shaping it.

\section{How to Read the Distributed Author?}

I say 'it', but, as we have seen, Fóstbrœðra saga (or indeed any saga, or any other traditional narrative for that matter) can be referred to in the singular only inasmuch as it is conceived of as a dynamic gathering of its various instances - in this case of $M$, $\mathrm{H}, \mathrm{F}$, and countless oral and written, known and anonymous other variants that these three had swallowed. As a traditional narrative, Fóstbrœðra saga is a "multiform", ${ }^{4}$ a "distributed object", ${ }^{55}$ something that is one and many all at once, always the same yet always different - just like the Danube is always the Danube (or Dunav, to me), even if, as Heraclitus warns, I can never step into the same Danube twice: it is always a different river that I step into, and always a different 'I' that does it. As such, despite some of the historically identifiable persons that left traces of their agency (all the more discernible for the saga's presently fragmented state), Fóstbrœðra saga can hardly be conceived of as a product of any one author, nor even of a multiplicity of authors where the relationship between the contributing individuals is merely additive. Rather, it is the product of the complex, networked, evolutionary dynamics between 'tradition and the individual talent' for which I some years ago proposed the term of 'distributed author'. ${ }^{56}$ 
Within this term which is a deliberate contradiction in terms, an oxymoron, the 'author' of the 'distributed author' is as far from the classical notions of the authorgenius as the word 'computer' is today from what it meant only a few decades ago, i.e. a person that does calculation. Rather, being modelled on the connectionist concept of distributed representation, ${ }^{57}$ the term invokes the creativity of neural networks and their precarious ontology, to which the present study consistently refers in terms of their being simultaneously one and many: many inputs (tradition, society, and culture in general) that must result in a single output (e.g. a particular performance of a story coming out of the mouth of a particular storyteller), which is in turn broadcast to many (i.e. its audiences; which is to say, back to tradition). Under such circumstances, any concrete, unique, local intentions and investments (which, according to the earlier discussed theories, are also always socially situated intentions and investments) - of the quirky (doctor-priest-French romance lover?) writer; of the erudite lawman Haukr Erlendsson; of the calculated compiler Jón Pórðarson; of the diligent (possibly also dissident) M scribe; of the expert and novice saga-tellers $\mathrm{X}, \mathrm{Y}, \mathrm{Z}$; of the changing audiences who wielded their praise and censure as narrative-shaping tools, sometimes even of the characters themselves, who, as was the case with historical and semi-historical figures such as the sworn brothers porgeirr and pormóðr, were the first to 'write' their own sagas with their deeds, which were in turn most likely modelled on the sagas to which they grew up listening - all these perspectives meet, compete, negotiate, overlay one another, mesh, coexist peacefully, or remain at odds in Fóstbrœðra saga and other such traditional narratives we read.

To return to the comment by Margaret Atwood with which we started - that is, that knowing who the author of a story is affects the way we read it - we must ask: what does this mean when the author of the narrative in front of us is the distributed author? My short answer to this question would be that distributed authorship calls for distributed reading. This means, for example, resisting the urge to choose a particular position on the hermeneutic pendulum ${ }^{58}$ - at whose one extreme point we might find porgeirr the noble retainer of a saintly king and on the other porgeirr the sociopathic committer of 'senseless violence' - in order to pay closer attention to the tensions arising between these 'porgeirrs' and the varied roles they are required to perform in response to the numerous, diverse, sometimes even contradictory factors involved in negotiating communal identity. It means considering this complex character in relation to other saga heroes trying to curb their fiery tempers (e.g. Grettir the Strong, Víga-Glúmr, VígaStyrr, etc.), heroes to whom the 'no reaction' formula is also often applied as they tread the narrow path between personal freedom and social responsibility, for finding the fine balance between these opposites must have been of great importance in a society keen 
to distinguish between feud as a means of enforcing law and justice on the one hand and revenge as a mere venting of personal anger on the other. It also means not dismissing the sagas' formulaic features and narrative patterns as clichés, but rather investigating whether, in between their more iterative and experimental usages within the corpus, we might gleam moments of deep pondering, of a community trying to make up 'its mind' about an issue, social practice, or aesthetic convention.

By their nature, short answers rarely prove to be satisfying. The long answer, however, warrants at least a separate study, though, in the 'network spirit' of the present chapter, working it out is bound to be a communal scholarly effort.

\section{Bibliography}

\section{Primary Sources}

AM 544 4to, URL: https://handrit.is/en/manuscript/view/en/AM04-0544 (last accessed 1 March 2021). Fóstbrœðra saga, in: Vestfirðinga søgur, ed. by Björn K. Pórólfsson / Guðni Jónsson, Reykjavík 1943 (Îslenzk Fornrit 6), pp. 119-276.

The Saga of the Sworn Brothers, tr. by Martin S. Regal, in: The Complete Sagas of Icelanders, including 49 Tales 2, ed. by Viðar Hreinsson, Reykjavík 1997, pp. 329-402.

\section{Secondary Sources}

Barthes $2000=$ Barthes, Roland: Death of the Author, in: Seán Burke (ed.): Authorship. From Plato to Postmodern. A Reader, Edinburgh 2000, pp. 125-130.

Chesnutt 2001 = Chesnutt, Michael: English Summary, in: Bjarni Einarsson (ed.): Egils saga Skallagrímsonnar. Bind I A-Redaktionen, København 2001 (Editiones Arnamagnæanæ 19).

Derrida 1982 = Derrida, Jacques: Margins of Philosophy, tr. by Alan Bass, Chicago 1982.

Dudai / Edelson 2016 = Dudai, Yadin / Edelson, Micah G.: Personal memory. Is it personal, is it memory?, in: Memory Studies 9.3 (2016), pp. 275-283.

Gatti 2016 = Gatti, Claudio: Elena Ferrante. An Answer?, in: The New York Review, 2 October 2016, URL: https://www.nybooks.com/daily/2016/10/02/elena-ferrante-an-answer/ (last accessed 1 March 2021).

Gell 1998 = Gell, Alfred: Art and Agency. An Anthropological Theory, Oxford 1998.

Guðni Jónsson 1943 = Guðni Jónsson: Formáli, in: Björn K. Pórólfsson / Guðni Jónsson (eds.): Vestfirðinga sǫgur, Reykjavík 1943 (Íslenzk fornrit 6).

Harris 2015 = Harris, Richard L.: 'Jafnan segir inn ríkri ráđ'. Proverbial Allusion and the Implied Proverb in Fóstbrœðra saga, in: Jeffrey Turco (ed.): New Norse Studies. Essays on the Literature and Culture of Medieval Scandinavia, Ithaca 2015, pp. 61-97.

Hirst / Brown 2011 = Hirst, William / Brown, Adam: On the Virtues of an Unreliable Memory. Its Role in Constructing Sociality, in: Gün R. Semin / Gerald Echterhoff (eds.): Grounding Sociality. Neurons, Mind and Culture, New York / London 2011, pp. 95-113. 
Johansson 2018 = Johansson, Karl G.: Compilations, collections and composite manuscripts. Some notes on the manuscript Hauksbók, in: Kate Heslop / Jürg Glauser (eds.): RE:writing. Medial perspectives on textual culture in the Icelandic Middle Ages, Zurich 2018 (Medienwandel - Medienwechsel Medienwissen 29), pp. 121-141.

Jónas Kristjánsson 1972 = Jónas Kristjánsson: Um Fóstbræðrasögu, Reykjavík 1972.

Lord $2000=$ Lord, Albert B.: The Singer of Tales, Cambridge (Mass.) $2000\left[1^{\text {st }}\right.$ ed. 1960].

McEwan 2011 = McEwan, Ian: Solar, London 2011.

Meulengracht Sørensen 1993 = Meulengracht Sørensen, Preben: On Humour, Heroes, Morality, and Anatomy in Fóstbrœðra saga, in: Peter Foote (ed.): Twenty-Eight Papers Presented to Hans BekkerNielsen on the Occasion of his Sixtieth Birthday, 28 April 1993, tr. by Peter Foote, Odense, pp. 395418.

Nelson 2003 = Nelson, Katherine: Self and Social Functions. Individual Autobiographical Memory and Collective Narrative, in: Memory 11.2 (2003), pp. 125-136.

Pavlus 2020 = Pavlus, John: Common Sense Comes Closer to Computers, in: Quanta magazine, 30 April 2020, URL: https://www.quantamagazine.org/common-sense-comes-to-computers-20200430/ (last accessed 1 March 2021).

Radford et al. 2019a = Radford, Alec / Wu, Jeffrey / Child, Rewon / Luan, David / Amodei, Dario / Sutskever, Ilya: Language Models are Unsupervised Multitask Learners, in: OpenAI, published 2019, URL: https://d4mucfpksywv.cloudfront.net/better-language-models/language_models_are_unsuper vised_multitask_learners.pdf (last accessed 1 March 2021).

Radford et al. 2019b = Radford, Alec / Wu, Jeffrey / Amodei, Dario / Amodei, Daniela / Clark, Jack / Brundage, Miles / Sutskever, Ilya: Better Language Models and Their Implications, in: OpenAI, 14 February 2019, URL: https://openai.com/blog/better-language-models/ (last accessed 1 March 2021).

Ranković / Ranković 2012 = Ranković, Slavica / Ranković, Miloš: The Talent of the Distributed Author, in: Slavica Ranković / Ingvil Brügger Budal / Aidan Conti / Leidulv Melve / Else Mundal (eds.): Modes of Authorship in the Middle Ages, Toronto 2012, pp. 52-75.

Ranković 2007 = Ranković, Slavica: Who Is Speaking in Traditional Texts? On the Distributed Author of the Sagas of Icelanders and Serbian Epic Poetry, in: New Literary History 38.2 (2007), pp. 239-307.

Ranković 2010 = Ranković, Slavica: Communal Memory of the Distributed Author: Applicability of the Connectionist Model of Memory to the Study of Traditional Narratives, in: Lucie Doležalová (ed.): The Making of Memory in the Middle Ages, Leiden / Boston 2010 (Later Medieval Europe 4), pp. 9-26.

Ranković 2016 = Ranković, Slavica: In the Refracted Light of the Mirror Phrases sem fyrr var sagt and sem fyrr var ritat. Sagas of Icelanders and the Orality-Literacy Interfaces, in:Journal of English and Germanic Philology 115.3 (2016), pp. 299-332.

Ranković 2017 = Ranković, Slavica: The Exquisite Tempers of Grettir the Strong, in: Scandinavian Studies 89.3 (2017), pp. 375-412.

Ranković 2018 = Ranković, Slavica: Remembering the Future, in: Jürg Glauser / Pernille Hermann / Stephen Mitchell (eds.): The Handbook of Pre-Modern Nordic Memory Studies, Berlin 2018, pp. 526-535.

Ranković 2020 = Ranković, Slavica: Twisted Mirror Twins: Porgeirr Hávarsson and Grettir the Strong, in: Saga-Book 44 (2020), pp. 81-138.

Rowe 2005 = Rowe, Elizabeth Ashman: The Development of Flateyjarbók. Iceland and the Norwegian Dynastic Crisis of 1389, Odense 2005 (The Viking Collection 15).

Savoy 2018 = Savoy, Jacques: Elena Ferrante Unmasked, in: Arjuna Tuzzi / Michele A. Cortelazzo (eds.): Drawing Elena Ferrante's Profile. Workshop Proceedings, Padova, 7 September 2017, Padova 2018, 
pp. 123-141, URL: http://www.padovauniversitypress.it/system/files/preview/9788869381300. pdf (last accessed 1 March 2021).

Schiappa / Rudd 2017 = Schiappa, Madeline / Rudd, Ethan: Man vs Machine: Comparing Artificial Intelligence and Biological Neural Networks, in: Sophos, 21 September 2017, URL: https://news. sophos.com/en-us/2017/09/21/man-vs-machine-comparing-artificial-and-biological-neuralnetworks/ (last accessed 1 March 2021).

Tuzzi / Cortelazzo 2018 = Tuzzi, Arjuna / Cortelazzo, Michele A.: Drawing Elena Ferrante's Profile. Workshop Proceedings, Padova, 7 September 2017, Padova 2018, URL: http://www.padova universitypress.it/system/files/preview/9788869381300.pdf (last accessed 1 March 2021).

Úlfar Bragason 2000 = Úlfar Bragason: Fóstbrœðra saga. The Flateyjarbók Version, in: Heinrich Beck / Else Ebel (eds.): Studien zur Isländersaga. Festschrift für Rolf Heller, Berlin / New York 2000, pp. 268-274.

Wang 2011 = Wang, Qi: Autobiographical Memory and Culture, in: Online Readings in Psychology and Culture 5.2 (2011), pp. 1-12. DOI: doi.org/10.9707/2307-0919.1047 (last accessed 1 March 2021).

Wilson 2016 = Wilson, Fiona: Margaret Atwood on Elena Ferrante and the Joys of Fiction, in: The Australian, 12 October 2016, URL: https://www.theaustralian.com.au/world/the-times/margaretatwood-on-elena-ferrante-and-the-joys-of-fiction/news-story/a06ab351aabc50bd2c0fb690 d4b44201 (last accessed 1 March 2021).

Winterson 2016 = Winterson, Jeanette: The malice and sexism behind the 'unmasking' of Elena Ferrante, in: The Guardian, 7 October 2016, URL: https://www.theguardian.com/books/2016/oct/07/ unmasking-elena-ferrante (last accessed 1 March 2021). 